\title{
Anesthetic activity and bio-guided fractionation of the essential oil of Aloysia gratissima (Gillies \& Hook.) Tronc. in silver catfish Rhamdia quelen
}

\author{
SIMONE C. BENOVIT ${ }^{1}$, LENISE L. SILVA ${ }^{1,6}$, JOSEÂNIA SALBEGO ${ }^{1}$, \\ VANIA L. LORO ${ }^{2}$, CARLOS A. MALLMANN ${ }^{3}$, BERNARDO BALDISSEROTTO ${ }^{1,4}$, \\ ERICO M.M. FLORES ${ }^{2}$ and BERTA M. HEINZMANN ${ }^{1,5}$ \\ ${ }^{1}$ Programa de Pós-Graduação em Farmacologia, Universidade Federal de \\ Santa Maria, Av. Roraima, 1000, 97105-900 Santa Maria, RS, 97105-900, Brasil \\ ${ }^{2}$ Departamento de Química, Universidade Federal de Santa Maria, \\ Av. Roraima, 1000, 97105-900 Santa Maria, RS, Brasil \\ ${ }^{3}$ Departamento de Medicina Veterinária Preventiva, Universidade Federal de \\ Santa Maria, Av. Roraima, 1000, 97105-900 Santa Maria, RS, Brasil \\ ${ }^{4}$ Departamento de Fisiologia e Farmacologia, Universidade Federal de \\ Santa Maria, Av. Roraima, 1000, Santa Maria, RS, 97105-900, Brasil \\ ${ }^{5}$ Departamento de Farmácia Industrial, Universidade Federal de \\ Santa Maria, Av. Roraima, 1000, 97105-900 Santa Maria, RS, Brasil \\ ${ }^{6}$ Laboratório de Farmacognosia e Química Farmacêutica, Universidade Regional Integrada do \\ Alto Uruguai e das Missões, Av. Batista Bonoto Sobrinho, 733, 97700-000 Santiago, RS, Brasil
}

Manuscript received on June 6, 2014; accepted for publication on December 5, 2014

\begin{abstract}
This work aimed to determine the efficacy of the essential oil of A. gratissima as anesthetic for silver catfish, and to perform the bio-guided fractionation of essential oil aiming to isolate compounds responsible for the noted effects. Fish were submitted to anesthesia bath with essential oil, its fractions and isolated compounds to determine time of anesthetic induction and recovery. Eugenol $\left(50 \mathrm{mg} \mathrm{L}^{-1}\right)$ was used as positive control. Essential oil of A. gratissima was effective as an anesthetic at concentrations of 300 to $900 \mathrm{mg} \mathrm{L}^{-1}$. Fish presented involuntary muscle contractions during induction and recovery. The bio-guided fractionation of essential oil furnished E-(-)-pinocamphone, (-)-caryophyllene oxide, (-)-guaiol and (+)-spathulenol. E-(-)pinocamphone caused the same side effects observed for essential oil. (-)-Caryophyllene oxide, (-)-guaiol and (+)-spathulenol showed only sedative effects at proportional concentrations to those of the constituents in essential oil. (+)-Spathulenol $\left(51.2 \mathrm{mg} \mathrm{L}^{-1}\right)$ promoted deep anesthesia without side effects. A higher concentration of (+)-spathulenol, and lower or absent amounts of $E$-(-)-pinocamphone could contribute to increase the activity and safety of the essential oil of A. gratissima. (+)-Spathulenol showed potent sedative and anesthetic activities in silver catfish, and could be considered as a viable compound for the development of a new anesthetic.
\end{abstract}

Key words: anesthesia, (-)-caryophyllene oxide, E-(-)-pinocamphone, (-)-guaiol, silver catfish, (+)-spathulenol.

Correspondence to: Berta Maria Heinzmann

E-mail: berta.heinzmann@gmail.com 


\section{INTRODUCTION}

There are different handling practices in fish farming, such as biometrics and transport. These practices can cause stress, which can be detrimental to animal performance. Anesthetics are used in this context to maintain fish welfare, minimizing stressful situations and facilitating handling (Coyle et al. 2004, Zahl et al. 2012). Natural products have been evaluated as an alternative to synthetic anesthetics, such as 2-phenoxyethanol, quinaldine sulfate and benzocaine, which may cause some side effects in fish and handlers (Inoue et al. 2003, Velisek et al. 2007). Some compounds isolated from plants, such as eugenol (Cunha et al. 2010a, Gomes et al. 2011, Becker et al. 2012) and menthol (Simões and Gomes 2009), and also some essential oils, such as the ones obtained from Eugenia caryophyllata (Inoue et al. 2003), Lippia alba (Cunha et al. 2010b, 2011), Ocimum gratissimum (Benovit et al. 2012, Silva et al. 2012) and Melaleuca alternifolia (Hajek 2011) have shown anesthetic activity on different fish species.

The genus Aloysia (Verbenaceae) is originally from South America, with 34 species cataloged, among which 12 can be found in Brazil (Cordo and Deloach 1995). Certain species of Aloysia are known to exhibit central activity. A. gratissima (Gillies \& Hook) Tronc. is known in Brazil as erva-santa (Souza and Wiest 20007), and has been used in folk medicine due to its sedative properties (Goleniowski et al. 2006). The essential oil of $A$. triphylla showed potent anesthetic activity in white shrimp (Litopenaeus vannamei) (Parodi et al. 2012) and silver catfish (Rhamdia quelen) (Gressler et al. 2014). Benovit et al. (2012) verified anesthetic activity of essential oil of $A$. gratissima in Brazilian flounder (Paralichthys orbignyanus). However, there are no studies correlating its depressant effect with some chemical constituent.

This work aimed to determine the efficacy of the essential oil obtained from leaves of $A$. gratissima (EOA) as anesthetic for silver catfish
(Rhamdia quelen), and to perform the bio-guided fractionation of EOA aiming to isolate the active compounds responsible for the noted effects. Acetylcholinesterase (AChE) activity under the influence of EOA was also investigated.

\section{MATERIALS AND METHODS}

\section{Plant Material}

Aerial parts of A gratissima were collected in April 2010 in Santa Maria, Rio Grande do Sul, Brazil. A voucher specimen (SMDB 13.077) was kept in the Biology Department of the Universidade Federal de Santa Maria and identified by Professor Marcos Sobral, UFSJ, and Professor Solon Jonas Longhi, UFSM.

ESSENTIAL OIL EXTRACTION

The essential oil was obtained from fresh leaves of A. gratissima by hydrodistillation with a Clevenger type apparatus for $3 \mathrm{~h}$ (British Pharmacopoeia 2007). Samples of the essential oil were stored at $-4^{\circ} \mathrm{C}$ in amber glass bottles prior to the tests or isolation.

Gas Chromatography Mass Spectrometry (GC-MS) AND NUCLEAR MAGNETIC RESONANCE (NMR) ANALYSIS

GC-MS analysis of EOA and fractions were performed using an Agilent-6890 gas chromatograph coupled with an Agilent 5973 mass selective detector, with an HP5-MS column (5\% phenyl - 95\% methylsiloxane, $30 \mathrm{~m} \times 0.25 \mathrm{~mm}$ i.d. $x 0.25 \mu \mathrm{m}$ ) and EI-MS of $70 \mathrm{eV}$. The isolated compounds were analyzed by a Varian CP-3800 gas chromatograph coupled to a Saturno mass selective detector, using VF-5 MS column (Varian, $30 \mathrm{~m}$ x $0.25 \mathrm{~mm} \times 0.25 \mu \mathrm{m})$. Conditions of analysis: injector $1177(\mathrm{MS}), 250^{\circ} \mathrm{C}$, split 1:20; injetor 1093 (FID), $250^{\circ} \mathrm{C}$. The operating conditions were: split inlet 1:100; temperature program, $40-320^{\circ} \mathrm{C}$ at $4^{\circ} \mathrm{C}$ $\mathrm{min}^{-1}$; carrier gas He; flow rate $1.3 \mathrm{~mL} \mathrm{~min}^{-1}$; injector and detector temperature $250^{\circ} \mathrm{C}$. The constituents were identified by comparing their Kovats retention 
index and mass spectra with a mass spectral library (NIST 2005) and literature data (Adams 2001).

Optical rotations were obtained on a Perkin Elmer 343 polarimeter. NMR spectra were recorded in $\mathrm{CDCl}_{3}$ on Bruker HPX 300 FT-NMR at $400 \mathrm{MHz}$ for ${ }^{1} \mathrm{H}$ and $100 \mathrm{MHz}$ for ${ }^{13} \mathrm{C}$ with TMS as internal standard.

FRACTIONATION AND ISOLATION OF ESSENTIAL OIL (EOA)

EOA $(6.03 \mathrm{~g})$ was first submitted to fractionation by column chromatography (CC, $3.5 \times 52 \mathrm{~cm}$ ) with $300 \mathrm{~g}$ silica gel 60 (Macherey-Nagel, 70-230 mesh) as stationary phase and hexane:acetone $(99: 1 \mathrm{v} / \mathrm{v})$ as mobile phase. The fractions obtained $(100 \mathrm{~mL}$ each) were gathered in 16 main fractions (Fractions A-P) based on TLC profile (silica gel F254; detection: anisaldehyde $\mathrm{H}_{2} \mathrm{SO}_{4}$ ). The fractions $\mathrm{G}$ and $\mathrm{J}$ were subsequently fractionated.

Fraction G (910.4 mg) was submitted to CC $(1.9 \times 61 \mathrm{~cm})$ with $89 \mathrm{~g}$ of silica gel 60 and eluted with henane:ethyl ether $(99: 1 \mathrm{v} / \mathrm{v})$ to obtain fractions of $20 \mathrm{~mL}$, resulting in 23 main fractions $\left(\mathrm{G}_{1-23}\right)$. The fraction $\mathrm{G}_{9}(167.7 \mathrm{mg})$ was rechromatographed by CC ( $1 \times 31.5 \mathrm{~cm})$ using $18 \mathrm{~g}$ of silica gel 60 impregnated with $10 \%$ silver nitrate (Williams and Mander 2001) and hexane:acetone $(99: 1 \mathrm{v} / \mathrm{v})$. Fractions of $10 \mathrm{~mL}$ were collected and pooled together to render 10 main fractions $\left(\mathrm{G}_{9 \mathrm{~A}-\mathrm{J}}\right)$. Purification of the main constituent of $\mathrm{G}_{9 \mathrm{~B}}(99.0 \mathrm{mg})$ was performed with CC (1 x 28.5 $\mathrm{cm})$ using $15 \mathrm{~g}$ silica gel 60 and eluted with chloroform:hexane:ethyl acetate $(78: 20: 2 \mathrm{v} / \mathrm{v} / \mathrm{v})$, to obtain $E$-(-)-pinocamphone [76.1 mg; EI-MS m/z (\%): $152\left(\mathrm{M}^{+}\right) ;[\alpha]_{\mathrm{D}}{ }^{20}=-24.54^{\circ}\left(c\right.$ 0.22, $\left.\left.\mathrm{CHCl}_{3}\right)\right]$ Fractions $\mathrm{G}_{17}-\mathrm{G}_{20}$ were gathered $(112.7 \mathrm{mg})$ and chromatographed by CC (1 x $30 \mathrm{~cm})$ using $16.31 \mathrm{~g}$ of silica gel 60 impregnated with $10 \%$ silver nitrate and hexane:ethyl acetate $(97: 3 \mathrm{v} / \mathrm{v})$ to provide (-)-caryophyllene oxide [91.1 mg; EI-MS m/z (\%): $\left.220\left(\mathrm{M}^{+}\right) ;[\alpha]_{\mathrm{D}}{ }^{20}=-62.5^{\circ}\left(c 0.24, \mathrm{CHCl}_{3}\right)\right]$. Fraction $\mathrm{J}(493.3 \mathrm{mg})$ was submitted to CC (1.6 x $47.5 \mathrm{~cm}$ ) with $48 \mathrm{~g}$ of silica gel 60 impregnated with $10 \%$ silver nitrate, using hexane:ethyl ether $(92: 8 \mathrm{v} / \mathrm{v})$ as eluent, and furnished (-)-guaiol [107.0 $\mathrm{mg}$; EI-MS m/z (\%): $222\left(\mathrm{M}^{+}\right) ;[\alpha]_{\mathrm{D}}{ }^{20}=-28.125^{\circ}(\mathrm{c}$ $\left.\left.0.16, \mathrm{CHCl}_{3}\right)\right]$ and (+)-spathulenol [91.3 mg; EI-MS $\left.\mathrm{m} / \mathrm{z}(\%): 220\left(\mathrm{M}^{+}\right) ;[\alpha]_{\mathrm{D}}{ }^{20}=+8.66^{\circ}\left(c 0.15, \mathrm{CHCl}_{3}\right)\right]$.

$E$-(-)-pinocamphone: ${ }^{1} \mathrm{H}$ NMR, $\delta$ (ppm): 0.84 (s, 3H, H9); 1.05 (d, 3H, H10); 1.12 (d, 1H, H7a); 1.29 (s, 3H, H8); 1.88 (dt, 1H, H1); 2.06 (m, 1H, H5); 2.38* (m, 1H, H4a); 2.41* (m, 1H, H7b); 2.57 (m, 1H; H2); $2.58(\mathrm{~m}, 1 \mathrm{H}, \mathrm{H} 4 \mathrm{~b})(*$ These values can be exchanged). ${ }^{13} \mathrm{C}$ NMR (ppm), $\delta: 14.96$ (C10); 19.70 (C9); 26.28 (C8); 29.04 (C7); 38.24 (C5); 39.36 (C6); 44.29 (C4); 44.39 (C1); 46.41 (C2); 215.34 (C3).

(-)-Caryophyllene oxide: ${ }^{1} \mathrm{H}$ NMR, $\delta$ (ppm): 0.9 (m, 1H, H); 0.91 (s, 3H, H13); 0.93 (s, 3H, H12); 1.13 (s, 3H, H14); 1.25 (m, 1H, H6a); 1.35 (m, 1H, H2a); 1.58 (m, 3H, H2b, H10a, H10b); 1.7 (m, 1H, H1); 2.02 (m, 1H, H3b); 2.03 (m, 1H, H7b); 2.17 (m, 1H, H6b); 2.27 (m, 1H, H7a); 2.54 (q, 1H, H9); 2.80 (dd, 1H, H5); 4.89 (s, 1H, H15a); 4.97 (s, 1H, H15b). ${ }^{13} \mathrm{C}$ NMR (ppm), $\delta: 16.94$ (C14); 21.59 (C13); 27.18 (C2); 29.78 (C7); 29.84 (C12); 30.14 (C6); 33.96 (C11); 39.12 (C3); 39.72 (C10); 48.68 (C9); 50.74 (C1); 59.74 (C4); 63.68 (C5); 112.69 (C15); 151.76 (C8).

(-)-Guaiol: ${ }^{1} \mathrm{H}$ NMR, $\delta$ (ppm): 0.94 (d, 3H, H14); 0.98 (d, 3H, H15); 1.14 (s, 3H, H12); 1.17 (s, $3 \mathrm{H}, \mathrm{H} 13$ ); 1.27, 1.95 (both m, 1H each, H3); 1.52 (m, 1H, H7); 1.70, 1.55 (both m, 1H each, H9); 1.80, 1.44 (both $\mathrm{m}, 1 \mathrm{H}$ each, H8); 2.13, 1.87 (dd, $\mathrm{m}$ respectively, $1 \mathrm{H}$ each, $\mathrm{H} 6) ; 2.28$ ( $\mathrm{m}, 1 \mathrm{H}, \mathrm{H} 10)$; 2.41, 2.05 (both m, $1 \mathrm{H}$ each, H2); 2.52 (dd, 1H, H4). ${ }^{13} \mathrm{C} \mathrm{NMR}, \delta$ (ppm): 19.69 (C15); 19.88 (C14); 25.93 (C12); 27.26 (C8); 27.31 (C13); 27.80 (C6); 30.91 (C3); 33.64 (C10); 33.73 (C9); 35.34 (C2); 46.27 (C4); 49.59 (C7); 73.48 (C11); 138.69 (C5); 140.07 (C1).

(+)-Spathulenol: ${ }^{1} \mathrm{H}$ NMR, $\delta(\mathrm{ppm}): 0.39(\mathrm{dd}$, 1H, H6); 0.64 (m, 1H, H7); 0.92 (m, 1H, H8b); 0.97 (s, 3H, H13); 0.98 (s, 3H, H12); 1.21 (s, 3H, H15); 1.25 (dd, 1H, H5); 1.48 (m, 1H, H3b); 1.55 (m, 1H, 
H2b); 1.70 (m, 1H, H3a); 1.83 (m, 1H, H2a); 1.91 (m, 1H, H8a); 1.98 (m, 1H, H9a); 2.14 (m, 1H, H1); 2.35 (dd, 1H, H9b); 4.60 (d, 2H, H14a/H14b). ${ }^{13} \mathrm{C} \mathrm{NMR,} \delta$ (ppm): 16.29 (C13); 20.21 (C11); 24.74 (C8); 26.03 (C15); 26.68 (C2); 27.46 (C7); 28.62 (C12); 29.90 (C6); 38.83 (C9); 41.71 (C3); 53.37 (C1); 54.27 (C5); 80.90 (C4); 106.22 (C14); 153.38 (C10).

ANIMALS

Silver catfish were purchased from local producers. Fish were kept in continuously aerated $250 \mathrm{~L}$ tanks for seven days for acclimatization under the same conditions of each experiment performed in sequence. A semi-static system was used, where $50 \%$ of the water volume was exchanged once a day. In experiment 1 , the water parameters were maintained at the following values: temperature, $15.90 \pm 0.14^{\circ} \mathrm{C} ; \mathrm{pH}, 7.37 \pm 0.11$; dissolved oxygen, $8.65 \pm 0.07 \mathrm{mg} \mathrm{L}^{-1}$; total ammonia, $2.43 \pm 0.81 \mathrm{mg}$ $\mathrm{L}^{-1}$ and unionized ammonia, $0.016 \mathrm{mg} \mathrm{L}^{-1}$. In the other experiments, the values were $19.33 \pm 0.69^{\circ} \mathrm{C}$; $\mathrm{pH}, 7.19 \pm 0.56$; dissolved oxygen, $6.61 \pm 0.95$; total ammonia, $1.06 \pm 0.39 \mathrm{mg} \mathrm{L}^{-1}$ and unionized ammonia, $0.006 \mathrm{mg} \mathrm{L}^{-1}$. Dissolved oxygen and temperature were measured with a YSI oxygen meter (model Y5512). The $\mathrm{pH}$ was verified with a DMPH-2 pH meter. Total ammonia levels were determined by the salicylate method (Verdouw et al. 1978). Fish were fed once a day until satiation with commercial feed for juveniles containing $28.0 \%$ of crude protein. The juveniles were fasted for $24 \mathrm{~h}$ prior to the experiments. The experimental methodologies were approved by the Ethical and Animal Welfare Committee of the Universidade Federal de Santa Maria (process No. 46/2010).

\section{EXPERIMENTAL PROCEDURE}

Three groups of experiments were performed to evaluate the sedative and anesthetic potential, as well as the recovery of silver catfish exposed to EOA, fractions and isolated compounds. Animals were transferred to aquaria containing $1 \mathrm{~L}$ of water and the samples to be tested, these samples were previously diluted in ethanol 95\% (1:10), to evaluate the time required to reach stages of anesthesia (Gomes et al. 2011). In this method, each juvenile was used only once in order to observe deep sedation (S2), partial (S3a) and total loss (S3b) of equilibrium, anesthesia (S4) and/or medullar collapse (S5). Anesthesia was determined by loss of reflex activity and no reaction to strong external stimuli (pressure on caudal peduncle). The animals remained in the anesthetic bath until they reached $\mathrm{S} 4$ or for $30 \mathrm{~min}$. After anesthesia induction, each fish was measured, weighed and transferred to an anesthetic-free aquarium to recover. The fish were considered to have recovered if their normal posture and behavior were restored, and the maximum time observed for this to occur was $30 \mathrm{~min}$. After that, the animals were transferred to $30 \mathrm{~L}$ aquariums, where possible side effects (spasms, contortions, secretion of mucus, seizures) or mortality was examined after $24 \mathrm{~h}$ of exposition. Control experiments were performed using aquarium containing ethanol at the highest concentration used to dilute the EOA.

In experiment 1 , the anesthetic activity of EOA was evaluated. Ten silver catfish juveniles $(6.82 \pm 2.04 \mathrm{~g} ; 9.10 \pm 0.91 \mathrm{~cm})$ were used for each concentration of EOA $(90,300,450$, or $900 \mathrm{mg}$ $\left.\mathrm{L}^{-1}\right)$. Experiment 2 was performed to compare the activity among $450 \mathrm{mg} \mathrm{L}^{-1} \mathrm{EOA}$ and the fractions with higher chromatographic yield obtained by column chromatography (B, D, F, G and J). Six juveniles $(8.66 \pm 2.32 \mathrm{~g} ; 9.52 \pm 0.86 \mathrm{~cm})$ were used for testing each fraction, at proportional concentrations to those of the major constituents in the EOA. In experiment 3, the sedative and anesthetic activities of the isolated compounds were evaluated. Six juveniles (6.99 $\pm 2.24 \mathrm{~g} ; 9.44$ $\pm 1.03 \mathrm{~cm}$ ) were used for each concentration. The isolated compounds were evaluated at proportional concentrations to those of the constituents in the EOA at concentrations of 450, 675 and $900 \mathrm{mg} \mathrm{L}^{-1}$, which corresponded to: $19.06,28.60$ and $38.14 \mathrm{mg}$ 
$\mathrm{L}^{-1}$ of $E$-(-)-pinocamphone; 10.00, 15.00, 20.00

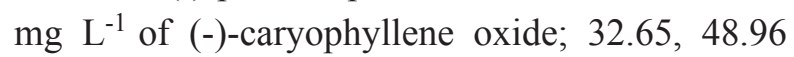
and $65.30 \mathrm{mg} \mathrm{L}^{-1}$ of (-)-guaiol; and 12.80, 19.20 and $25.60 \mathrm{mg} \mathrm{L}^{-1}$ of (+)-spathulenol. Additional concentrations of (-)-caryophyllene oxide $(40 \mathrm{mg}$ $\left.\mathrm{L}^{-1}\right)$ and (+)-spathulenol (51.20 $\left.\mathrm{mg} \mathrm{L}^{-1}\right)$ were tested. $(-)$-Guaiol and $(+)$-spathulenol were also evaluated together (32.65 and $12.80 \mathrm{mg} \mathrm{L}^{-1}$, respectively). Eugenol at concentration of $50 \mathrm{mg} \mathrm{L}^{-1}$ was used as positive control (Cunha et al. 2010a).

\section{LONG EXPOSURE TIME}

This experiment evaluated the effects of long exposure time (24h) of silver catfish to EOA and $(+)$-spathulenol at sedative concentrations. Considering the sedative concentrations determined in the experiments described in the previous sections, four experimental groups were evaluated: EOA at $90 \mathrm{mg} \mathrm{L}^{-1},(+)$-spathulenol at $2.6 \mathrm{mg} \mathrm{L}^{-1}$ (proportional concentration of the constituent in the EOA at $90 \mathrm{mg} \mathrm{L}^{-1}$ ), ethanol (at the concentration used to dilute the EOA) and water.

Silver catfish $(6.72 \pm 2.01 \mathrm{~g} ; 8.75 \pm 1.02 \mathrm{~cm})$ were transferred to aquaria containing $1 \mathrm{~L}$ of water and the sample to be tested. Six animals were used for each group to determine the time it would take to reach stage S3a. Initially, animal condition was evaluated in the first $30 \mathrm{~min}$ of exposure to confirm the occurrence of sedation and then after $24 \mathrm{~h}$, aiming to evaluate the toxicity of the substances during this time. After exposure, fish were transferred to anesthetic-free $7 \mathrm{~L}$ aquariums, where possible signs of intoxication or mortality were examined for an additional $24 \mathrm{~h}$.

\section{ACETYLCHOLINESTERASE ASSAY}

Six silver catfish juveniles $(20.49 \pm 6.71 \mathrm{~g} ; 16.50$ $\pm 1.33 \mathrm{~cm}$ ) were exposed to each concentration of EOA $\left(90,300\right.$ or $\left.450 \mathrm{mg} \mathrm{L}^{-1}\right)$, firstly diluted in ethanol 95\% (1:10). Control experiments were performed using water alone or ethanol at the highest concentration used to dilute the EOA.
Fish were euthanized by severing the spinal cord after they reached $\mathrm{S} 4$ or after $30 \mathrm{~min}$ of exposure (control group and concentrations that did not promote anesthesia). Whole brain and muscle samples were removed, packed in eppendorf tubes and kept at $-20^{\circ} \mathrm{C}$ for $\mathrm{AChE}$ analysis. AChE assay was performed in homogenates of brain and muscle according to the method described by Ellman et al. (1961) and modified by Villescas et al. (1981). Homogenates $(50-100 \mu \mathrm{L})$ were incubated with 0.8 $\mathrm{mM}$ of acetylthiocholine and $1.0 \mathrm{mM}$ of 5,5'-dithiobis-2-nitrobenzoic acid (DTNB) at $25^{\circ} \mathrm{C}$ for 2 min. Protein content was determined according to Bradford (1976). Enzyme activity was expressed as micromoles of acetylthiocholine hydrolyzed per minute per milligram of protein.

\section{STATISTICAL ANALYSIS}

Values are presented as mean \pm SEM (standard error of the mean). A Levene test was used with all data to verify the homogeneity of variances. The results were analyzed by one-way ANOVA and Tukey test or Kruskal-Wallis and Dunn test, when appropriate. Comparison between spathulenol and eugenol was performed with t-test. The minimum significance level was set at $\mathrm{P}<0.05$. Regression analyses were performed to EOA and isolated compounds.

\section{RESULTS}

The yield of EOA was $1.94 \pm 0.03 \%(w / w)$. EOA showed 73 constituents, and $91.86 \%$ of the chemical composition was identified. The major compounds of EOA were 1,8-cineole (18.54\%), sabinene $(9.5 \%)$, guaiol $(6.79 \%)$ and bicyclogermacrene (5.12\%) (Table I).

Silver catfish reached anesthesia with EOA at concentrations ranging from 300 (approximately $18 \mathrm{~min}$ ) to $900 \mathrm{mg} \mathrm{L}^{-1}$ (approximately $12 \mathrm{~min}$ ). Fish exposed to $90 \mathrm{mg} \mathrm{L}^{-1}$ reached stage $3 \mathrm{a}$ after $8 \mathrm{~min}$ and they remained in this stage for $30 \mathrm{~min}$ of observation. There were no significant differences in the induction times to anesthesia 
TABLE I

Chemical composition of essential oil of Aloysia gratissima and fractions of higher yield.

\begin{tabular}{|c|c|c|c|c|c|c|c|c|c|}
\hline \multirow{2}{*}{$\begin{array}{c}\text { RT } \\
(\mathrm{min})\end{array}$} & \multirow{2}{*}{ Constituents } & \multirow{2}{*}{$\begin{array}{c}\text { Essential } \\
\text { oil }(\%)\end{array}$} & \multicolumn{5}{|c|}{ Fractions (\%) } & \multirow{2}{*}{ RI calc } & \multirow{2}{*}{ RI ref } \\
\hline & & & $\mathbf{B}$ & D & $\mathbf{F}$ & $\mathbf{G}$ & $\mathbf{J}$ & & \\
\hline 9.756 & $\alpha$-pinene & 2.74 & 7.91 & & & & & 931.0 & 932 \\
\hline 11.459 & sabinene & 9.50 & 44.26 & & & & & 973.0 & 972 \\
\hline 11.518 & $\beta$-pinene & 3.69 & 15.76 & & & & & 974.1 & 973 \\
\hline 12.205 & $\beta$-myrcene & 1.27 & & & & & & 990.9 & 990 \\
\hline 13.679 & limonene & 2.34 & 9.90 & & & & & 1027.1 & 1029 \\
\hline 13.820 & 1,8-cineole & 18.54 & & & 31.19 & 9.51 & & 1030.5 & 1031 \\
\hline 15.232 & $Z$-sabinene hydrate & 1.13 & & & & & & 1065.2 & 1070 \\
\hline 16.477 & $E$-sabinene hydrate & 0.60 & & & & & & 1095.8 & 1098 \\
\hline 18.056 & $E$-pinocarveol & 0.89 & & & & & & 1136.1 & 1139 \\
\hline 18.345 & $E$-verbenol & 0.50 & & & & & & 1143.5 & 1145 \\
\hline 18.951 & $E$-pinocamphone & 3.99 & & & 14.40 & 30.21 & & 1159.0 & 1163 \\
\hline 19.455 & $Z$-pinocamphone & 1.33 & & & & 8.96 & & 1171.9 & 1175 \\
\hline 20.136 & $\alpha$-terpineol & 0.63 & & & & & & 1189.3 & 1189 \\
\hline 20.328 & myrtenol & 0.63 & & & & & & 1194.2 & 1196 \\
\hline 24.215 & $E$-pinocavyl acetate & 2.84 & & & 34.37 & 12.05 & & 1299.6 & 1298 \\
\hline 25.520 & $\delta$-elemene & 0.85 & & & & & & 1337.2 & 1338 \\
\hline 27.409 & $\beta$-elemene & 0.63 & & & & & & 1391.8 & 1391 \\
\hline 28.323 & $\beta$-caryophyllene & 2.82 & 9.30 & & & & & 1419.2 & 1419 \\
\hline 28.806 & $\gamma$-elemene & 0.60 & & & & & & 1433.8 & 1437 \\
\hline 29.440 & $\alpha$-caryophyllene & 0.87 & & 5.82 & & & & 1453.1 & 1455 \\
\hline 30.372 & germacrene D & 3.91 & & 7.16 & & & & 1481.4 & 1482 \\
\hline 30.883 & bicyclogermacrene & 5.12 & & 49.38 & & & & 1496.9 & 1497 \\
\hline 31.456 & cubebol & 0.68 & & & & & & 1515.4 & 1515 \\
\hline 32.529 & elemol & 0.73 & & & & & & 1550.6 & 1550 \\
\hline 32.772 & germacrene B & 4.15 & & 21.14 & & & & 1558.6 & 1560 \\
\hline 33.426 & spathulenol & 2.71 & & & & & 30.53 & 1580.0 & 1582 \\
\hline 33.586 & caryophyllene oxide & 2.16 & & & & 18.96 & & 1585.3 & 1585 \\
\hline 34.063 & guaiol & 6.79 & & & & & 30.87 & 1601.0 & 1601 \\
\hline \multirow[t]{2}{*}{36.095} & bulnesol & 2.38 & & & & & 9.12 & 1670.4 & 1672 \\
\hline & Total identified & 91.86 & & & & & & & \\
\hline
\end{tabular}

*(\%): Relative percentage; Rt: Retention time; RI cal: calculated Kovats retention index; RI ref: reference Kovats retention index. Components in amounts below $0.5 \%$ in the essential oil have been omitted. Only major constituents of the fractions of higher yield obtained from EOA were shown.

between the concentrations of 450 and $900 \mathrm{mg} \mathrm{L}^{-1}$, but these induction times (approximately $12 \mathrm{~min}$ ) were significantly faster than those of $300 \mathrm{mg} \mathrm{L}^{-1}$. A significant relationship between the EOA concentration and the time required for anesthesia induction was noted for all stages (Table II), except for recovery time. Time of recovery was significantly faster at $900 \mathrm{mg} \mathrm{L}^{-1}$ (approximately $12 \mathrm{~min}$ ) when compared to 300 and $450 \mathrm{mg} \mathrm{L}^{-1}$. During this experiment, and $24 \mathrm{~h}$ after it, no mortality occurred. However, involuntary muscle contractions were observed in the fish submitted to EOA during induction and recovery. The group exposed to ethanol showed light sedation (S2 in 
TABLE II

Time (s) required for anesthesia induction and recovery using different concentrations of EOA in Rhamdia quelen.

\begin{tabular}{|c|c|c|c|c|c|}
\hline \multirow{2}{*}{$\begin{array}{l}\text { Concentration } \\
\left(\mathrm{mg} \mathrm{L}^{-1}\right)\end{array}$} & \multicolumn{4}{|c|}{ Time of induction to anesthesia (s) } & \multirow{2}{*}{$\begin{array}{c}\text { Time of } \\
\text { recovery }(s)\end{array}$} \\
\hline & Stage 2 & Stage 3a & Stage 3b & Stage 4 & \\
\hline 90 & $89.17 \pm 25.92^{\mathrm{a}}$ & $519.20 \pm 30.91^{\mathrm{a}}$ & - & - & $956.60 \pm 78.46^{\mathrm{ab}}$ \\
\hline 300 & $39.90 \pm 7.12^{\mathrm{a}}$ & $163.10 \pm 12.35^{\mathrm{b}}$ & $875.10 \pm 29.95^{\mathrm{a}}$ & $1085.70 \pm 45.54^{\mathrm{a}}$ & $1083.14 \pm 91.35^{\mathrm{a}}$ \\
\hline 450 & $16.60 \pm 1.18^{\mathrm{b}}$ & $74.40 \pm 4.32^{\mathrm{c}}$ & $669.10 \pm 38.58^{\mathrm{b}}$ & $776.10 \pm 33.68^{b}$ & $1188.12 \pm 57.19^{\mathrm{a}}$ \\
\hline 900 & $15.70 \pm 1.86^{\mathrm{b}}$ & $36.30 \pm 1.94^{\mathrm{d}}$ & $593.00 \pm 54.50^{\mathrm{b}}$ & $720.90 \pm 36.11^{\mathrm{b}}$ & $746.60 \pm 54.81^{\mathrm{b}}$ \\
\hline \multirow[t]{2}{*}{ Equations } & $\mathrm{y}=12.56+128.64^{(-\mathrm{x} / 175.71)}$ & $\begin{array}{c}\ln y=8.37- \\
0.104 \ln (x)^{2}\end{array}$ & $\begin{array}{c}\mathrm{y}=0.002 \mathrm{x}^{2}- \\
2.88 \mathrm{x}+1558.05\end{array}$ & $\begin{aligned} y= & 0.003 x^{2}-4.49 x \\
& +2141.7\end{aligned}$ & - \\
\hline & $r^{2}=0.984$ & $\mathrm{r}^{2}=0.988$ & $r^{2}=1$ & $r^{2}=1$ & - \\
\hline
\end{tabular}

*Values are means \pm SEM. Different letters in the columns indicate significant differences among concentrations by one-way ANOVA and Tukey tests (S3b, S4 and recovery) or by Kruskal-Wallis and Dunn tests (S2 and S3a) $(\mathrm{P}<0.05)$. (-) indicates that the stage was not reached within $30 \mathrm{~min}$ or that there was no significant relationship.

approximately $7.9 \mathrm{~min}$ ), but it was significantly different from all EOA-treated groups.

AChE activity did not show any significant difference among treatments (Table III).

The fractions B, D, F, G and J showed higher yield from the EOA chromatography process. Similar chemical composition was verified for fractions $F$ and $G$, while the others showed different major constituents (Table I). No sedative effect was observed for fraction $\mathrm{D}$ in silver catfish within 30 min of exposure. Fish exposed to fractions $\mathrm{B}$ and $\mathrm{F}$ reached only S3a (Table IV). Both fractions G and $\mathrm{J}$ resulted in anesthesia (S4) in $50 \%$ of fish with no significant differences between them. However, fraction $\mathrm{G}$ caused involuntary muscle contractions similar to those verified with the EOA. Fraction J caused no side effects, but it resulted in increased recovery time in relation to the other fractions. Since fractions $G$ and $J$ showed anesthetic or side effects, we chose to isolate their constituents in order to identify the possible active compounds. E-(-)-pinocamphone and (-)-caryophyllene oxide were obtained from fraction $\mathrm{G}$, while purification of fraction $\mathrm{J}$ resulted in the isolation of (-)-guaiol and (+)-spathulenol. The isolated constituents were identified by comparing the MS and NMR data with literature reports (Coxon et al. 1984, Raharivelomana et al. 1995, Chaves and Santos 2002, Höld et al. 2002, Bolzan 2007).

TABLE III

Brain and muscle specific AChE activity ( $\mu \mathrm{mol} \mathrm{min}^{-1}$ mg protein $^{-1}$ ) of Rhamdia quelen exposed to EOA.

\begin{tabular}{cccccc}
\hline \multirow{2}{*}{ Tissue } & \multicolumn{4}{c}{ Treatments } \\
\cline { 2 - 5 } & \multirow{2}{*}{ Water control } & \multirow{2}{*}{ Ethanol control } & \multicolumn{3}{c}{ EOA (mg L $\left.\mathbf{~ L}^{-1}\right)$} \\
\cline { 4 - 6 } & & $\mathbf{9 0}$ & $\mathbf{3 0 0}$ & $\mathbf{4 5 0}$ \\
\hline Brain & $0.693 \pm 0.098^{\mathrm{a}}$ & $0.702 \pm 0.082^{\mathrm{a}}$ & $0.672 \pm 0.093^{\mathrm{a}}$ & $0.612 \pm 0.064^{\mathrm{a}}$ & $0.645 \pm 0.028^{\mathrm{a}}$ \\
Muscle & $0.853 \pm 0.130^{\mathrm{a}}$ & $0.723 \pm 0.047^{\mathrm{a}}$ & $0.743 \pm 0.064^{\mathrm{a}}$ & $0.943 \pm 0.128^{\mathrm{a}}$ & $1.080 \pm 0.151^{\mathrm{a}}$ \\
\hline
\end{tabular}

*Values are means \pm SEM. Data was submitted to one-way ANOVA $(\mathrm{P}<0.05)$.

Juveniles submitted to $E$-(-)-pinocamphone showed different behavior of sedated or anesthetized fish. In the first minutes of exposure, a period of hyperactivity could be noted. Animals tended to present faster and erratic swimming with partial loss of equilibrium, and sudden jumping towards the 
TABLE IV

Time (s) required for induction and recovery from anesthesia using EOA (at concentration of $450 \mathrm{mg} \mathrm{L}^{-1}$ ) and their fractions of higher yield (at proportional concentrations to those of the major constituents in the EOA) in Rhamdia quelen.

\begin{tabular}{cccccc}
\hline \multirow{2}{*}{ Fraction } & \multicolumn{5}{c}{ Time of induction to anesthesia (s) } \\
\cline { 2 - 5 } & Stage 2 & Stage 3a & Stage 3b & Stage 4 & \\
\hline EOA & $6.67 \pm 0.99^{\mathrm{b}}$ & $37.33 \pm 2.86^{\mathrm{b}}$ & $930.60 \pm 290.64^{\mathrm{a}}$ & $1035.33 \pm 226.44^{\mathrm{a}}$ & $894.00 \pm 67.79^{\mathrm{ab}}$ \\
B & $83.33 \pm 19.11^{\mathrm{a}}$ & $762.50 \pm 52.50^{\mathrm{a}}$ & - & - & $213.00 \pm 16.18^{\mathrm{c}}$ \\
D & - & - & - & - & - \\
F & $99.33 \pm 32.87^{\mathrm{a}}$ & $608.00 \pm 91.38^{\mathrm{a}}$ & - & - & $272.50 \pm 15.73^{\mathrm{c}}$ \\
G & $23.83 \pm 2.09^{\mathrm{ab}}$ & $67.33 \pm 10.60^{\mathrm{b}}$ & $279.00 \pm 96.77^{\mathrm{a}}$ & $894.67 \pm 150.36^{\mathrm{a}}$ & $587.50 \pm 95.97^{\mathrm{b}}$ \\
$\mathrm{J}$ & $37.00 \pm 15.01^{\mathrm{ab}}$ & $92.67 \pm 32.46^{\mathrm{b}}$ & $1138.33 \pm 210.90^{\mathrm{a}}$ & $1457.00 \pm 94.12^{\mathrm{a}}$ & $1119.00 \pm 220.40^{\mathrm{a}}$ \\
\hline
\end{tabular}

*Values are means \pm SEM. Different letters in the columns indicate significant difference among treatments by one-way ANOVA and Tukey tests (stages 3a, 3b, 4 and recovery) or Kruskal-Wallis and Dunn tests (stage 2) $(\mathrm{P}<0.05)$. (-) indicates that the stage was not reached within $30 \mathrm{~min}$.

water surface. Afterwards, there was a period of total loss of equilibrium, animals tumbled on the bottom of the aquarium and remained immobile even after pressure on caudal peduncle, but they responded to external stimuli made with a glass rod in the bottom of the aquarium. Then, fish went back to swimming erratically, and, at that moment, involuntary muscle contractions were noted. Fish writhed to the right and left, or remained contracted in "C or S-shape". There was a significant relationship between the concentration of $E$-(-)-pinocamphone and the time required for hyperactivity stage $(\mathrm{y}=283.198-$ $\left.15.111 \mathrm{x}+0.228 \mathrm{x}^{2} ; \mathrm{r}^{2}=1\right)$ and tipping stage $(\mathrm{y}=$ $\left.-13.117+18.650 x-0.406 x^{2} ; r^{2}=1\right)$. Three juveniles were found dead $24 \mathrm{~h}$ after the experiment.

The other isolated compounds reached stages $\mathrm{S} 2$ and S3a at proportional concentrations to EOA. Sedation (S2) obtained with (-)-caryophyllene oxide was not significantly different from EOA, except at the lowest concentration tested, or (+)-spathulenol (Fig. 1a). EOA was the most effective for loss of equilibrium (S3a), except at concentration of $675 \mathrm{mg} \mathrm{L}^{-1}$, where it did not differ from (+)-spathulenol. (-)-Caryophyllene oxide and (-)-guaiol did not present statistical differences to reach stage S3a, except at the highest concentration, in which (-)-caryophyllene oxide was more effective (Fig. 1b). In addition, both compounds showed different induction times from EOA.

(-)-Caryophyllene oxide (ln $y=0.769+$ $\left.35.066 / \mathrm{x} ; \mathrm{r}^{2}=0.995 ; \mathrm{N}=6\right),(-)$-guaiol (ln $\mathrm{y}=1.18$ $\left.+0.039 \mathrm{x} ; \mathrm{r}^{2}=0.999 ; \mathrm{N}=6\right)$, and $(+)$-spathulenol $\left(\mathrm{y}=28.28+6.333 \mathrm{x}-0.377 \mathrm{x}^{2}+0.005 \mathrm{x}^{3} ; \mathrm{r}^{2}=1 ;\right.$ $\mathrm{N}=6$ ) showed a significant relationship between the concentrations and the time required to reach stage $\mathrm{S} 2$. The regression equations to reach stage S3a were $y=-3873.656+874.635 x-48.433 x^{2}$ $+0.725 \mathrm{x}^{3} ; \mathrm{r}^{2}=1 ; \mathrm{N}=6$ to (-)-caryophyllene oxide, $\ln \mathrm{y}=3.42+17.2 / \mathrm{x}^{0.5} ; \mathrm{r}^{2}=0.999 ; \mathrm{N}=6$ to $(-)$-guaiol and $\mathrm{y}=453.198-11.955 \mathrm{x}-0.285 \mathrm{x}^{2}$ $+0.007 \mathrm{x}^{3} ; \mathrm{r}^{2}=1 ; \mathrm{N}=6$ to $(+)$-spathulenol. (-)-Caryophyllene oxide $(\mathrm{y}=2901.2-495.21 \mathrm{x}$ $\left.+27.753 \mathrm{x}^{2}-0.411 \mathrm{x}^{3} ; \mathrm{r}^{2}=1 ; \mathrm{N}=6\right)$ and (-)-guaiol $\left(\mathrm{y}=1676.76-59.58 \mathrm{x}+0.68 \mathrm{x}^{2} ; \mathrm{r}^{2}=1 ; \mathrm{N}=6\right)$ also showed significant relationships between the concentrations and recovery times. There was no significant difference in the recovery time of juveniles submitted to concentrations of 12.8 to $25.6 \mathrm{mg} \mathrm{L}^{-1}$ of (+)-spathulenol (data not shown). (-)-Caryophyllene oxide, (-)-guaiol and (+)-spathulenol did not promote mortality during induction and recovery and also $24 \mathrm{~h}$ after exposition, while four fish exposed to EOA were found dead $24 \mathrm{~h}$ after the experiment. Fish submitted 

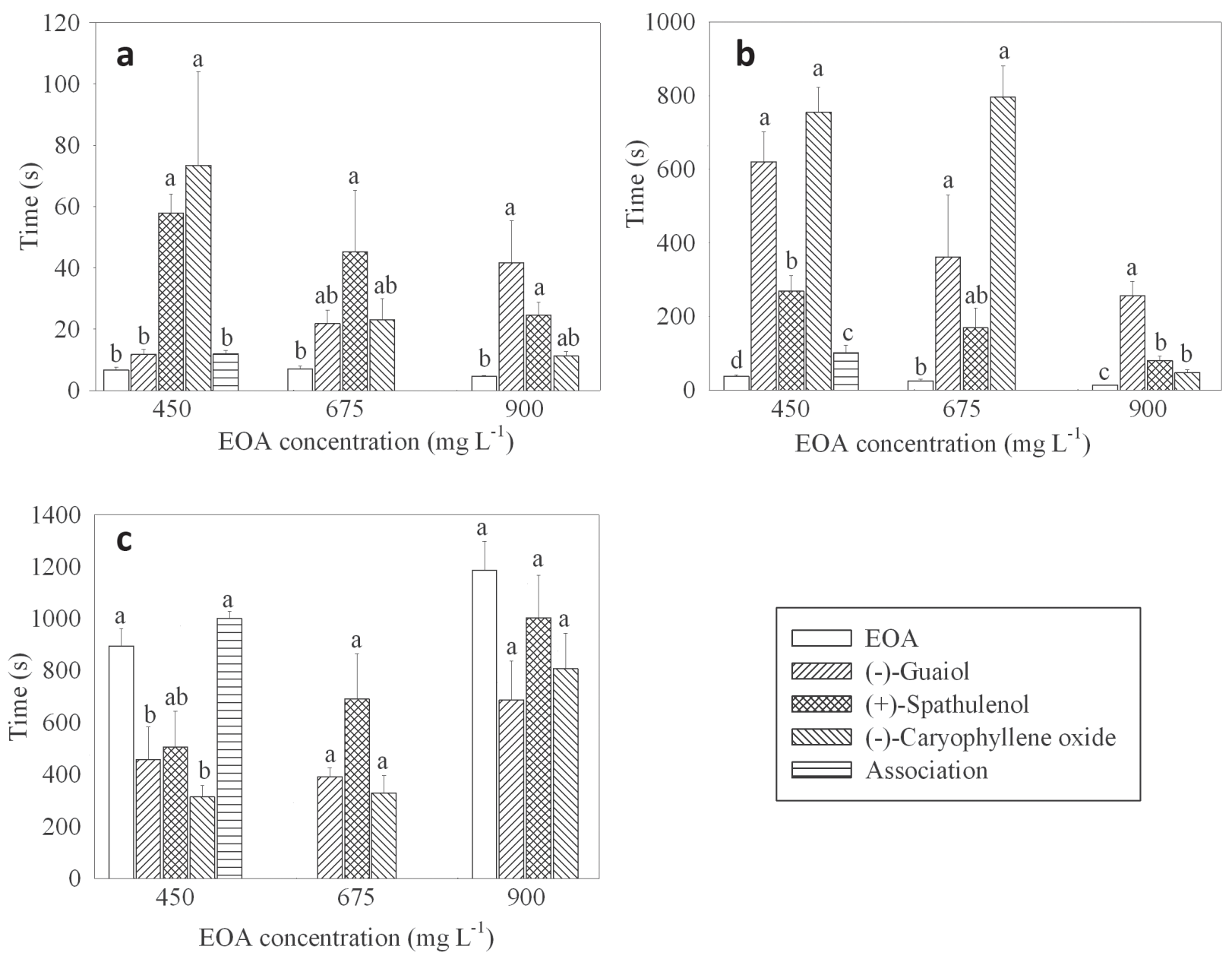

Figure 1 - Time required for the induction and recovery from sedation in silver catfish submitted to EOA and the isolated compounds at proportional concentrations to those of the constituents in EOA: (a): Stage 2; (b): Stage 3a; (c): Recovery. For 450 mg L ${ }^{-1}$ EOA: (-)-guaiol (32.65 $\left.\mathrm{mg} \mathrm{L}^{-1}\right)$, (+)-spathulenol $\left(12.8 \mathrm{mg} \mathrm{L}^{-1}\right)$, (-)-caryophyllene oxide $\left(10 \mathrm{mg} \mathrm{L}^{-1}\right)$ and association of (-)-guaiol and (+)-spathulenol (32.65 and $12.8 \mathrm{mg} \mathrm{L}^{-1}$ ); For $675 \mathrm{mg} \mathrm{L}^{-1}$ EOA: (-)-guaiol (48.96 mg L ${ }^{-1}$ ), (+)-spathulenol (19.2 $\left.\mathrm{mg} \mathrm{L}^{-1}\right)$ and (-)-caryophyllene oxide $\left(15 \mathrm{mg} \mathrm{L}^{-1}\right)$; For $900 \mathrm{mg} \mathrm{L}^{-1}$ EOA, (-)-guaiol (65.3 mg L $\left.\mathrm{mg}^{-1}\right)$, (+)-spathulenol (25.6 mg L $\left.\mathrm{m}^{-1}\right)$ and (-)-caryophyllene oxide $\left(20 \mathrm{mg} \mathrm{L}^{-1}\right)$. Fish submitted to $675 \mathrm{mg} \mathrm{L}^{-1}$ EOA did not recover within 30 min, so it was not shown in this figure. Stages are according to Gomes et al. (2011). Maximum observation time was $30 \mathrm{~min}$. $\mathrm{N}=6$ for each concentration tested. Data are expressed as mean \pm SEM. Different letters indicate a significant difference between the different products at the same stage. Stage S3a and recovery time of $675 \mathrm{mg} \mathrm{L}^{-1}$ EOA and S2 of $900 \mathrm{mg} \mathrm{L}^{-1}$ EOA were submitted to Kruskal-Wallis and Dunn tests $(\mathrm{P}<0.05)$. The other stages were submitted to ANOVA and Tukey tests $(\mathrm{P}<0.05)$.

to (-)-caryophyllene oxide (40 $\left.\mathrm{mg} \mathrm{L}^{-1}\right)$ and (-)-guaiol (48.96 and $65.30 \mathrm{mg} \mathrm{L}^{-1}$ ) showed secretion of mucus during exposition, whereas (-)-caryophyllene oxide (15 - $40 \mathrm{mg} \mathrm{L}^{-1}$ ) caused light spasms in the animals.

(-)-Caryophyllene oxide did not promoted anesthesia even at the highest concentration tested (40 $\mathrm{mg} \mathrm{L}^{-1}$ ). Stage S2 and S3a were reached at $5.50 \pm 0.22 \mathrm{~s}$ and $25.50 \pm 4.29 \mathrm{~s}$, respectively, with 40 $\mathrm{mg} \mathrm{L}^{-1}$ of this compound. Moreover, fish recovered after $1168.00 \pm 126.08 \mathrm{~s}$. Fish exposed to $51.2 \mathrm{mg} \mathrm{L}^{-1}$ of (+)-spathulenol reached S2 and S3a faster than with the positive control eugenol (Fig. 2). (+)-Spathulenol promoted deep anesthesia in approximately $22 \mathrm{~min}$, which was a significantly different time, than that obtained with eugenol, which was of approximately 13 min, to reach the same stage. Recovery after 


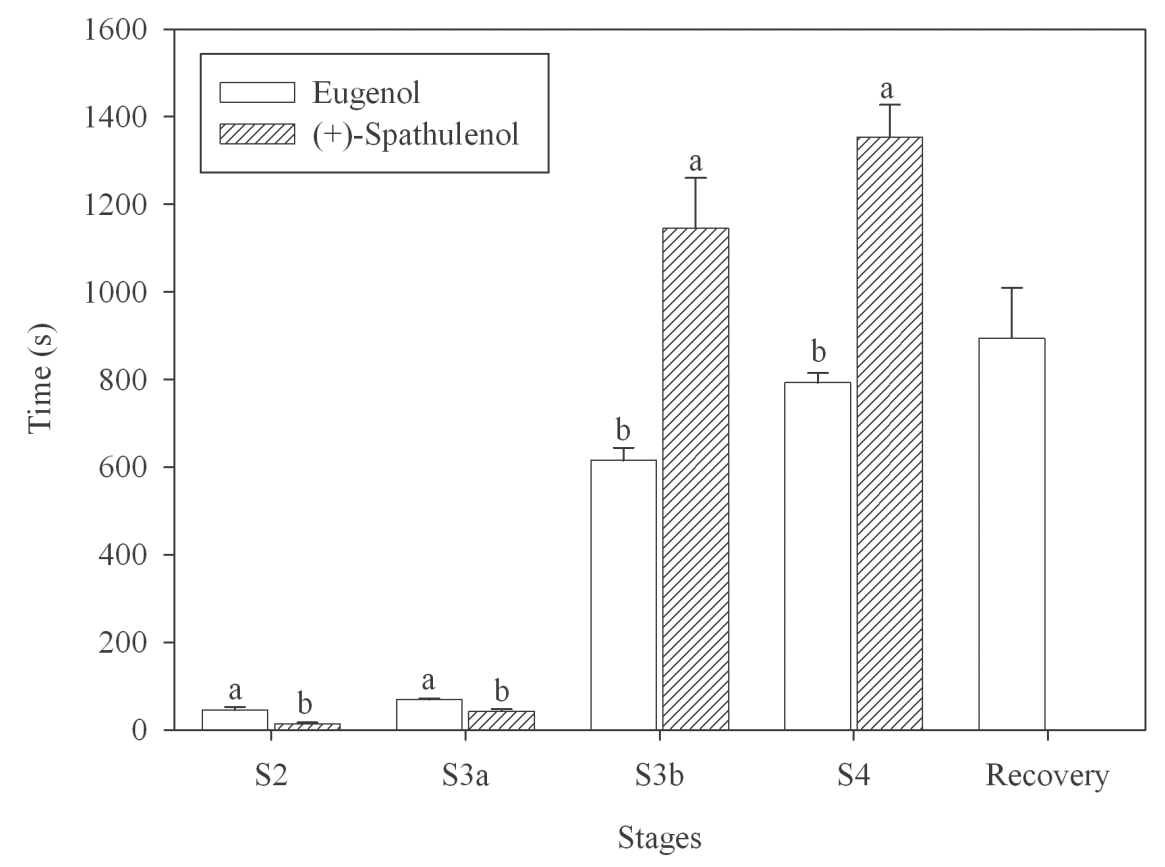

Figure 2 - Time required for the induction of sedation and anesthesia in silver catfish submitted to (+)-spathulenol $\left(51.20 \mathrm{mg} \mathrm{L}^{-1}\right)$ in comparison with eugenol $\left(50 \mathrm{mg} \mathrm{L}^{-1}\right)$. Stages are according to Gomes et al. (2011). Maximum observation time was $30 \mathrm{~min}$. N=6 for each concentration tested. Data are expressed as mean $\pm \mathrm{SEM}$. Different letters indicate a significant difference between the different products at the same stage using t-test $(\mathrm{P}<0.05)$.

eugenol exposure occurred in approximately $15 \mathrm{~min}$, while fish exposed to $(+)$-spathulenol did not recover within $30 \mathrm{~min}$.

The association of (-)-guaiol and (+)-spathulenol resulted in decrease of induction time until stage S3a, when compared to the isolated compounds (Fig. 1b). However, animals submitted to this association showed mucus secretion and greater recovery time than with the isolated compounds (Fig. 1c). When compared with EOA, the recovery time of the association did not differ statistically. The three isolated compounds did not show statistical differences in the recovery time at all concentrations. Moreover, only one fish submitted to EOA recovered within $30 \mathrm{~min}$ at the concentration of $675 \mathrm{mg} \mathrm{L}^{-1}$.

Regarding the long exposure time (24h), fish reached $\mathrm{S} 3 \mathrm{a}$ at $241.50 \pm 20.28 \mathrm{~s}$ with $\mathrm{EOA}$ and $1752.50 \pm 70.94 \mathrm{~s}$ with (+)-spathulenol. After $24 \mathrm{~h}$ of exposure, no mortality was observed, and the animals submitted to EOA and (+)-spathulenol were not sedated. Fish submitted to $(+)$-spathulenol did not present signs of intoxication or mortality after $24 \mathrm{~h}$ in anesthetic-free aquaria. However, $33.33 \%$ of mortality was observed with EOA.

\section{DISCUSSION}

Previous studies showed quantitative differences in the chemical composition of the EO obtained from leaves of A. gratissima. Dambolena et al. (2010) identified 1,8-cineole (45.5\%) and sabinene (8.3\%) as major constituents. However, the proportion of these compounds found by these authors was different from the corresponding data found in the present study. Similar proportion of guaiol (6.27\%) was found by Franco et al. (2007). Varied amounts of bicyclogermacrene $(0-12.8 \%)$ were described by Ricciardi et al. (2006), and this variation depended on sites and period of collection. 
Anesthesia (S4) is achieved when fish lose reflex activity and do not show a reaction to strong external stimuli (Gomes et al. 2011). Silver catfish exposed to concentrations of $300-900 \mathrm{mg} \mathrm{L}^{-1}$ EOA reached this stage within 12-18 min. The concentration of $900 \mathrm{mg} \mathrm{L}^{-1}$ was the most effective, because it showed lower anesthetic induction and recovery time. Similar EOA concentrations (270$900 \mathrm{mg} \mathrm{L}^{-1}$ ) also provoked deep anesthesia in Brazilian flounder (Benovit et al. 2012). To reach the same level of anesthesia in a similar period of time (approximately $12 \mathrm{~min}$ ) in silver catfish, 30 $\mathrm{mg} \mathrm{L}^{-1}$ of eugenol and $100 \mathrm{mg} \mathrm{L}^{-1}$ of EO of Lippia alba are made necessary (Cunha et al. 2010a, b). Moreover, $200 \mu \mathrm{L} \mathrm{L}^{-1}$ of EO of Melaleuca alternifolia and $250 \mathrm{mg} \mathrm{L}^{-1}$ of menthol lead to S4 in common carp, Cyprinus carpio, and in Nile tilapia, Oreochromis niloticus, respectively (Simões and Gomes 2009, Hajek 2011).

The fractionation process showed that compounds present in fraction D did not contribute to the depressor effects of EOA, while constituents of the fractions $\mathrm{B}$ and $\mathrm{F}$ could be involved in its sedative effect. Previous reports described central activity for some compounds present in fractions $\mathrm{B}$ and $\mathrm{F}$, such as limonene, 1,8-cineol, $\alpha$ - and $\beta$-pinene (Kasanen et al. 1998, Santos and Rao 2000, Vale et al. 2002), which need to be confirmed in aquatic animals. On the other hand, fractions $\mathrm{G}$ and $\mathrm{J}$ promoted anesthesia in $50 \%$ of fish, which indicates that the compounds present in these fractions contribute to the anesthetic effect of EOA.

The involuntary muscle contractions and mortality observed in fish exposed to EOA and/ or fraction $\mathrm{G}$ may be explained by the presence of E-(-)-pinocamphone in these samples. Additionally, with this isolated compound the fish showed two distinct stages, hyperactivity and tipping. Similar effects were characterized as seizure in zebrafish, Danio renio, exposed to caffeine, pentylenetetrazole (PTZ) and picrotoxin (Wong et al. 2010). E- and $Z$-pinocamphone are known antagonists of gamma- aminobutyric acid type $\mathrm{A}\left(\mathrm{GABA}_{\mathrm{A}}\right)$ receptor (Höld et al. 2002). These compounds are able to promote convulsions in mouse that can be alleviated by diazepam, and their signs of intoxication are similar to picrotoxin (Höld et al. 2002). As fish submitted to $E$-(-)-pinocamphone showed more intense side effects than EOA, the compounds with sedative/ anesthetic activity present in EOA may have reduced their effects.

The results obtained for $E$-(-)-pinocamphone are not inconsistent with the results of the AChE assay of EOA. Action in AChE was researched because the muscle inhibition of this enzyme leads to increased acetylcholine levels, resulting in excessive muscular stimulation (Kirby et al. 2000). However, AChE activity was not affected by EOA at the tested concentrations and, therefore, the contractures observed on the fish were not due to alterations in the activity of this enzyme. On the other hand, this response could be attributed, as reported earlier, to the GABAergic system, and future studies should be conducted to clarify this issue.

(-)-Caryophyllene oxide and (-)-guaiol promoted sedation at all tested concentrations. Higher concentrations of these compounds were not used because they caused mucus secretion on the animals. Additionally, (-)-caryophyllene oxide showed light spasm in fish. Secretion of mucus has been observed with some synthetic anesthetics for fish, such as 2-phenoxyethanol, quinaldine sulfate and benzocaine (Inoue et al. 2003, Velisek et al. 2007); as well as 2,4-D [(2,4-dichlorophenoxy) acetic acid], a herbicide (Sarikaya and Yilmaz 2003). Caryophyllene oxide, isolated from the Psidium guajava, showed depressant effects on the central nervous system of mice, through potencialization of the pentobarbital induced-sleeping time (Meckes and Calzada 1996). However, studies on the central activity of (-)-guaiol were not found.

Sedation induced by (+)-spathulenol is in accordance with those described for the EO obtained from Baccharis uncinella, which showed sedative 
effects in mice and contains spathulenol as one of the major constituents (Ascari et al. 2012). There were no other studies related to the central activity of $(+)$-spathulenol. Since this compound did not cause any side effects at sedative concentrations, one higher concentration was tested, which resulted in anesthesia. In this concentration, fish submitted to $(+)$-spathulenol showed faster sedation, slower anesthesia and recovery, than eugenol. Eugenol is largely used as anesthetic for fish and its activity has been proven in different species (Vidal et al. 2007, Honczaryk and Inoue 2009, Cunha et al. 2010a, Gomes et al. 2011, Becker et al. 2012). On the other hand, (+)-spathulenol promoted anesthesia in lower concentrations $\left(51.2 \mathrm{mg} \mathrm{L}^{-1}\right)$ than $S$-(+)-linalool (153 $\left.\mathrm{mg} \mathrm{L}^{-1}\right)$ isolated from the EO of $L$. alba in silver catfish (Heinzmann et al. 2011). Additionally, with $S$-(+)-linalool, fish did not recover within 30 min, similar to $(+)$-spathulenol in the present study.

(+)-Spathulenol at $2.6 \mathrm{mg} \mathrm{L}^{-1}$ was shown to be a safe compound to sedate silver catfish for $24 \mathrm{~h}$. An opposite pattern occurred with EOA, because mortality was noted after exposure for the same period of time. Spathulenol at $8 \mathrm{mg} \mathrm{L}^{-1}$ for $24 \mathrm{~h}$ was classified by Ito et al. (2004) as ichthyotoxic in medaka, Oryzias latipes. It is probable that this concentration of spathulenol led to S5 of anesthesia induction (medullar collapse) and thus, caused mortality to this fish. An anesthetic may induce different results due to variations between fish species (Zahl et al. 2012).

A relationship between concentration and recovery time was noted in fish exposed to (-)-caryophyllene oxide and (-)-guaiol, while the other tested compounds did not show the same relation. Studies with eugenol and EO of L. alba in silver catfish also showed that the concentration of these substances did not influence in the recovery time (Cunha et al. 2010a, b).

The fractionation of EOA resulted in a decrease of the anesthetic potential. The isolated compounds did not promote anesthesia at proportional concentrations to those of the constituents in the EOA. Moreover, the association of (-)-guaiol and (+)-spathulenol caused a decrease in the time required to reach stage S3a. These evidences indicate that the anesthetic and sedative effects are due to the synergism of the constituents present in EOA. Similar results were observed regarding the anticonvulsive activity of the EO of Ocimum gratissimum in mice. Moreover, the EO of this plant was more effective, than their major constituents tested alone or in association, eugenol, 1,8-cineole and $E$-caryophyllene, which were evaluated in the same proportion found for the EO (Galindo et al. 2010).

Conversely, the hypothesis that the minor constituents are responsible for the anesthetic activity of EOA in silver catfish cannot be ruled out, since the fractions of lower yield were not tested. Essential oils contain several substances, which can show different mechanisms of action. These different mechanisms can act in synergy resulting in improved activity (Harris 2002), but antagonism can also occur (Savelev et al. 2003). Pharmacokinetic synergism can also be observed, where absorption, distribution, biotransformation or elimination of a compound can be influenced by other substance, obtaining positive results (Spinella 2002).

EOA showed anesthetic properties, however, it should be used carefully in silver catfish due to the observed side effects. Additionally, EOA had a higher induction time than ideal, of 3-5 $\mathrm{min}$ (Cunha et al. 2010b). The presence of $E$-(-)-pinocamphone and (-)-caryophyllene oxide contributed to the side effects of EOA, whereas anesthetic activity was partially related to (+)-spathulenol. Then, higher concentration of $(+)$-spathulenol, and lower or absent amounts of $E$-(-)-pinocamphone, could contribute to improve the anesthetic activity and safety of the EOA. (+)-Spathulenol was considered a promising anesthetic and sedative for aquatic animals. 


\section{ACKNOWLEDGMENTS}

This study was supported by Conselho Nacional de Desenvolvimento Científico e Tecnológico (CNPq; process 470964/2009-0) and Fundação de Amparo à Pesquisa do Estado do Rio Grande do Sul - Programa de Apoio a Núcleos de Excelência (FAPERGS - PRONEX; process 10/0016-8). B. Baldisserotto received a research fellowship from $\mathrm{CNPq}$ and S.C. Benovit, J. Salbego and L.L. Silva received a graduate fellowships from Coordenação de Aperfeiçoamento de Pessoal de Nível Superior (CAPES, Brazil) The authors are grateful to Professor Marcos Sobral (UFSJ, MG) and Professor Solon Jonas Longhi (UFSM, RS) for the identification of A. gratissima.

\section{RESUMO}

Este trabalho tem como objetivo determinar a eficácia do óleo essencial de A. gratissima como anestésico para jundiás, bem como realizar o fracionamento bioguiado do óleo essencial a fim de isolar os compostos responsáveis pelos efeitos observados. Os peixes foram submetidos ao banho-anestésico com óleo essencial, suas frações e compostos isolados para determinar o tempo de indução e recuperação da anestesia. O eugenol $(50 \mathrm{mg}$ $\left.\mathrm{L}^{-1}\right)$ foi utilizado como controle positivo. O óleo essencial de $A$. gratissima promoveu anestesia em concentrações de 300 a $900 \mathrm{mg} \mathrm{L}^{-1}$. Os peixes apresentaram contrações musculares involuntárias durante indução e recuperação. Com o fracionamento bio-guiado do óleo essencial foram obtidos E-(-)-pinocanfona, (-)-óxido de cariofileno, (-)-guaiol e (+)-espatulenol. A E-(-)-pinocanfona promoveu os mesmos efeitos adversos observados com o óleo essencial. (-)-Óxido de cariofileno, (-)-guaiol e (+)-espatulenol demonstraram apenas efeitos sedativos nas concentrações proporcionais ao óleo essencial. $\mathrm{O}(+)$-espatulenol $\left(51.2 \mathrm{mg} \mathrm{L}^{-1}\right)$ promoveu anestesia profunda sem efeitos adversos. Uma maior concentração de (+)-espatulenol e menores quantidades ou ausência de $E$-(-)-pinocanfona poderiam contribuir para melhorar a atividade anestésica e segurança do óleo essencial de A. gratissima. O (+)-espatulenol apresentou potente atividade sedativa e anestésica em jundiás, e poderia ser considerado um composto viável para o desenvolvimento de um novo anestésico.

Palavras-chave: anestesia, (-)-óxido de cariofileno, E-(-)-pinocanfona, (-)-guaiol, jundiá, (+)-espatulenol.

\section{REFERENCES}

ADAMS RP. 2001. Identification of essential oil components by gas chromatography/quadrupole mass spectroscopy. Allured Publishing Corporation, Illinois, $456 \mathrm{p}$.

ASCARI J, SENS SL, NUNES DS, WiSNIEWSKI JR A, ARBo MD, LINCK VM, LUNARDI P, LEAL MB AND ELISABETSKY E. 2012. Sedative effects of essential oils obtained from Baccharis uncinella. Pharm Biol 50: 113-119.

BeCker AG, PARodi TV, Heldwein CG, ZePPENFELd CC, Heinzmann BM And Baldisserotto B. 2012. Transportation of silver catfish, Rhamdia quelen, in water with eugenol and the essential oil of Lippia alba. Fish Physiol Biochem 38: 789-796.

Benovit SC, GRESSLER LT, Silva LL, GARCIA LO, OKAMOTO MH, PEDRON JS, SAMPaIO LA, Rodrigues RV, HEINZMANN BM AND BALDISSEROTTO B. 2012. Anesthesia and transport of Brazilian flounder, Paralichthys orbignyanus, with essential oils of Aloysia gratissima and Ocimum gratissimum. J World Aquac Soc 43: 896-900.

BolzAN AA. 2007. Constituents of Senecio platensis Arech.: isolation, structural elucidation and evaluation of the antibacterial activity. MSc. Thesis (Ciências Farmacêticas), Universidade Federal de Santa Maria, RS, Brazil, 150 p. (Unpublished).

BRADFORD MMA. 1976. A rapid and sensitive method for the quantification of microgram quantities of protein utilizing the principle of protein-dye binding. Anal Biochem 72: 248-254.

BRITISH PHARMACOPOEIA. 2007. Her Majesty's Stationery Office, London.

Chaves MCO and Santos BVO. 2002. Constituents from Piper marginatum fruits. Fitoterapia 73: 547-549.

CORDO HA AND DeloACh CJ. 1995. Natural enemies of the rangeland weed whitebrush (Aloysia gratissima: Verbenaceae) in South America: potential for biological control in the United States. Biol Control 5: 218-230.

COXON JM, HydES GJ AND STEEL PJ. 1984. Carbon-13 nuclear magnetic resonance spectra of pinane monoterpenoids. J Chem Soc Perkin Trans 2: 1351-1355.

Coyle SD, Durborow RM AND Tidwell JH. 2004. Anesthetics in aquaculture. SRAC Publication 3900.

Cunha MA, Barros FMC, Garcia LO, VeECK APL, HeINZMANN BM, LORO VL, EMANUElli T AND BALDisserotTo B. 2010b. Essential oil of Lippia alba: a new anesthetic for silver catfish, Rhamdia quelen. Aquaculture 306: 403-406. 
Cunha MA, Silva BF, Delunardo FAC, Benovit SC, GOMES LC, HEINZMANN BM AND BALDISSEROTTO B. 2011. Anesthetic induction and recovery of Hippocampus reidi exposed to the essential oil of Lippia alba. Neotrop Ichthyol 9: 683-688.

CUNHA MA, ZEPPENFELD CC, GARCIA LO, LORO VL, FonseCA MB, EMANUElli T, VEECK APL, COPATTI CE AND BALDISSEROTTO B. 2010a. Anesthesia of silver catfish with eugenol: time of induction, cortisol response and sensory analysis of fillet. Cienc Rural 40: 2107-2114.

DAMBOLENA JS, ZUNINO MP, LUCINI EI, ZYGADLO JA, BANCHIO E, BIURRUN F, ROTMAN A AND AHUMADA O. 2010. Aromatic plants of northwest Argentina. Constituents of the essential oils of aerial parts of seven Verbenaceae: Lantana and Aloysia. J Essent Oil Res 22: 289-293.

ELlMAN GL, COURTNEY KD, ANDRES JR V AND FEATHERSTONE RM. 1961. A new and rapid colorimetric determination of acetylcholinesterase activity. Biochem Pharmacol 7: 88-95.

Franco ALP, OlIVEIRA TB, FERri PH, BARA MTF AND PAULA JR. 2007. Evaluation of the chemical composition and antibacterial activity of essential oils of Aloysia gratissima (Gillies \& Hook) Tronc., Ocimum gratissimum L. and Curcuma longa L. Rev Eletr Farm 4: 208-220.

GAlindo LA, PULTRInI AM AND COSTA M. 2010. Biological effects of Ocimum gratissimum L. are due to synergic action among multiple compounds present in essential oil. J Nat Med 64: 436-441.

Goleniowski ME, BONGIOVANNI GA, PALACIO L, NUÑEZ CO AND CANTERO JJ. 2006. Medicinal plants from the "Sierra de Comechingones", Argentina. J Ethnopharmacol 107: 324-341.

Gomes DP, Chaves BW, BECKER AG AND BALDISSEROtTO B. 2011. Water parameters affect anaesthesia induced by eugenol in silver catfish, Rhamdia quelen. Aquac Res 4: 878-886.

GRESSLER LT ET AL. 2014. Silver catfish Rhamdia quelen immersion anaesthesia with essential oil of Aloysia triphylla (L'Hérit) Britton or tricaine methanesulfonate: effect on stress response and antioxidant status. Aquac Res 45: 1061-1072.

HAJEK GJ. 2011. The anaesthetic-like effect of tea tree oil in common carp Cyprinus carpio L. Aquac Res 42: 296-300.

HARRIS R. 2002. Synergism in the essential oil world, Int. J Aromath 12: 179-186.

Heinzmann BM, Baldisserotto B, Flores EMM, Schmidt D, CARon BO, Souza VQ, Heldwein CG, PArodi TV, GaI EZ AND ROMAN C. 2011. Processo de obtenção de composto anestésico de Lippia alba, composto anestésico obtido e uso de composto como anestésico. Brazilian Patent PI1103966-3.

HöLd KM, SiRISOMA NS, SPARKS SE AND CASIDA JE. 2002. Metabolism and mode of action of cis- and trans3 -pinanones (the active ingredients of hyssop oil). Xenobiotica 32: 251-265.

HONCZARYK A AND INOUE LAKA. 2009. Anesthesia in pirarucu by eugenol sprays in the gills. Cienc Rural 39: 577-579.
InOUE LAKA, Neto CS AND MorAes G. 2003. Clove oil as anesthetic for juveniles of matrinxã Brycon cephalus (Gunther, 1869). Cienc Rural 33: 943-947.

ITO H, IWAMORI H, KasaJima N, KANEDA M AND YoshidA T. 2004. Kunzeanones A, B, and C: novel alkylated phloroglucinol metabolites from Kunzea ambigua. Tetrahedron 60: 9971-9976.

KasAnen JP, PASANEN AL, PASANEN P, LiesivuORI J, Kosma VM AND ALARIE Y. 1998. Stereospecificity of the sensory irritation receptor for nonreactive chemicals illustrated by pinene enantiomers. Arch Toxicol 72: 514-523.

Kirby MF, Morris S, Hurst M, Kirby SJ, NEAll P, Tylor T AND FAGG A. 2000. The use of cholinesterase activity in flounder (Platichthys flesus) muscle tissue as a biomarker of neurotoxic contamination in UK estuaries. Mar Pollut Bull 40: 780-791.

MeCKES M AND CAlzAdA F. 1996. Terpenoids isolated from Psidium guajava hexane extract with depressant activity on central nervous system. Phytother Res 10: 600-603.

NIST - NATIONAL INSTITUTE OF STANDARDS AND TECHNOLOGY. 2005. Mass spectral library and search/ analysis programs. J Wiley \& Sons Hoboken.

PARODI TV ET AL. 2012. The anesthetic efficacy of eugenol and the essential oils of Lippia alba and Aloysia triphylla in post-larvae and sub-adults of Litopenaeus vannamei (Crustacea, Penaeidae). Comp Biochem Physiol C Toxicol Pharmacol 155: 462-468.

RAHARIVELOMANA P, BIANCHINI JP, CAMBON A, AZZARO M AND FAURE R. 1995. Two-dimensional NMR of sesquiterpenes. 8-complete assignment of ${ }^{1} \mathrm{H}$ and ${ }^{13} \mathrm{C}$ NMR spectra of seven sesquiterpene alcohols from Neocallitropsis pancheri. Magn Reson Chem 33: 233-235.

RICCIARDI GAL, VAN BAREN CM, LIRA PDL, RICCIARDI AIA, Lorenzo D, Dellacassa E AND BANDONI AL. 2006. Volatile constituents from aerial parts of Aloysia gratissima (Gillies \& Hook.) Tronc. var. gratissima growing in Corrientes, Argentina. Flavour Fragr J 21: 698-703.

SANTOS FA AND RAO VSN. 2000. Antiinflammatory and antinociceptive effects of 1,8-cineole, a terpenoid oxide present in many plant essential oils. Phytother Res 14: 240-244.

SARIKAYARAND YILMAZM. 2003. Investigation of acute toxicity and the effect of 2,4-D (2,4-dichlorophenoxyacetic acid) herbicide on the behavior of the common carp (Cyprinus carpio L., 1758; Pisces, Cyprinidae). Chemosphere 52: 195-201

SAVelev S, OKello E, Perry NSL, Wilkins RM and Perry EK. 2003. Synergistic and antagonistic interactions of anticholinesterase terpenoids in Salvia lavandulifolia essential oil. Pharmacol Biochem Behav 75: 661-668.

Silva LL, PARodi TV, RECKZIEgEl P, GARCIA VO, BÜRGER ME, Baldisserotto B, Malmann CA, Pereira AMS AND HEINZMANN BM. 2012. Essential oil of Ocimum gratissimum L.: anesthetic effects, mechanism of action and tolerance in silver catfish, Rhamdia quelen. Aquaculture 350-353: 91-97. 
SIMÕES LN AND GOMES LC. 2009. Menthol efficiency as anesthetic for juveniles Nile tilapia Oreochromis niloticus. Arq Bras Med Vet Zootec 61: 613-620.

SouZA AA AND WIEST JM. 2007. Antibacterial activity of Aloysia gratissima (Gill et Hook) Tronc. (garupá, herbsaint), used in the traditional medicine in Rio Grande do Sul State - Brazil. Rev Bras P1 Med 9: 23-29.

SPINELLA M. 2002. The importance of pharmacological synergy in psychoactive herbal medicines. Altern Med Rev 7: 130-137.

Vale tG, Furtado EC, SAntos JR JG and Viana GS. 2002. Central effects of citral, myrcene and limonene, constituents of essential oil chemotypes from Lippia alba (Mill.) N.E. Brown. Phytomedicine 9: 709-714.

VeliseK J, Wlasow T, GomulKa P, Svobodova Z AND NOVOTNY L. 2007. Effects of 2-phenoxyethanol anaesthesia on sheatfish (Silurus glanis L.). Vet Med (Praha) 52: 103-110.

Verdouw H, VAN EChTELd CJA AND DEKKERS EMJ. 1978. Ammonia determination based on indophenol formation with sodium salicylate. Water Res 12: 399-402.
VIDAL LVO, FURUYA WM, GRACIANO TS, SCHAMBER CR, SANTOS LD AND SOARES CM. 2007. Eugenol concentrations for deep anesthesia and acute toxicity in piavuçu (Leporinus macrocephalus) juveniles. Acta Sci Biol Sci 29: 357-362.

VILLESCAS R, OSWALD R AND MARIMOTO H. 1981. Effects of neonatal under nutrition and cold stress on behavior and biochemical brain parameters in rats. J Nutr 111: 1103-1110.

WILLIAMS CM AND MANDER LN. 2001. Chromatography with silver nitrate. Tetrahedron 57: 425-447.

WONG K ET AL. 2010. Modeling seizure-related behavioral and endocrine phenotypes in adult zebrafish. Brain Res 1348: 209-215.

ZAHL IH, SAMUELSEN O AND KIESSLING A. 2012. Anaesthesia of farmed fish: implications for welfare. Fish Physiol Biochem 38: 201-218. 
